\title{
Comparison of Narcissistic Personality Characteristics of Faculty of Education Students and Sport Science Students
}

\author{
Haluk Koç ${ }^{1}$, Latif Aydos ${ }^{1}$, Hacı Ahmet Pekel ${ }^{1}$ \\ ${ }^{1}$ Faculty of Sports Sciences, Physical Education and Sports Teaching Department, Gazi University, Turkey \\ Correspondence: Haluk Koç, Faculty of Sports Sciences, Physical Education and Sports Teaching Department, Gazi \\ University, Turkey.
}

Received: July 3, 2018 Accepted: August 2, $2018 \quad$ Online Published: August 15, 2018

doi:10.11114/jets.v6i10.3404

URL: https://doi.org/10.11114/jets.v6i10.3404

\begin{abstract}
Narcissistic Personality Levels of the students of the Faculty of Education and the students of the Faculty of Sports Sciences in terms of age, gender, active sports doing, department, graduated high school, mother education level, father education level, mother profession and father profession variables have been examined in this study. A total of 364 university students enrolled in the Faculty of Education and the Faculty of Sports Sciences in Gazi University, Hacettepe University and Ankara University, in the academic year 2017-2018 has constituted the research group. Descriptive statistics on narcissistic personality scores; analysis of variance (one-way ANOVA, independent sample t-test) to compare average scores in unrelated measures, the Tukey test to determine which groups had significant differences, have been used. According to the results of the research, the students of the Faculty of Sports Sciences showed more narcissistic personality tendency than the students of the Faculty of Education.
\end{abstract}

Keywords: narcissism, education and sports

\section{Introduction}

The concept of narcissism comes from Narkissos, who falls in love with himself seeing his reflection in water and who lives out his own life by following this beloved that he can never reach in his life (Turkish Language Society, 2009; Tazegül 2018). Narcissism, in the sense of the dictionary, is understood to mean the sexual desire and pleasure which one leads to his/ her body (Özsaydın, 1984). The most important feature of narcissism is that selfness (selfness-covers living, perceived spiritual and physical, entire individual apart from other objects existing in the external world) is put forward steeply, and the reduction of interest for others.

Narcissism was first used in 1898 by psychoanalytic theorist Ellis to explain a psychological concept, and Ellis explained narcissism emotions, involving to direct libidos to individuals himself (Rozenblatt, 2002, as cited in Karaaziz \& Atak 2013). The first important work on narcissism is Freud's "an introduction to Narcissism". This study is considered to be the basis of narcissism in psychoanalysis. But unlike many researchers, Freud has considered narcissism as a phenomenon, not a condition. As a type of personality, he mentioned about the narcissism first time in 1931.

Psychoanalytic thinking has continued to develop itself after Freud. Many theorists and therapists have continued to discuss on the normal personality and psychological disorder by using and developing the concepts developed by Freud (Crider et all., 1983, as cited in Timuroğlu \& İşcan, 2008).

One of these names Kohut (1977), states that the origin of the narcissistic personality disorder is the person's "basic defect in self-organization". Persons with narcissistic personality disorder are those who over-appreciate themselves physically and mentally, look themselves superior, constantly waiting for appreciation, interest and approval; are people who believe that they will see special attention immediately wherever they go, that they deserve a superior place (Karaaziz \& Atak, 2013; Özakkaş, 2006; Kohut, 1971). The most beautiful, the most handsome, the most successful, the brightest person will be s/he or s/he will be. Within such intense narcissistic expectations, disappointments and offenses can be so frequent. The individual's self-esteem is nourished by interest, appreciation, and approval from the outside. The people in question can not stand the criticism and they always wait for praise (Kohut, 1977).

Narcism is necessary for a person to survive, work and maintain a solid identity, is a normal condition for human psychology. But when you go through some obstacles, a weakened or swollen self can lead to self-love. All of the 
repetitive thoughts, behaviors and emotions that people exhibit when exaggerated self-love are called "narcissistic personality". Narcissistic personality disorder is defined as the feeling of superiority that starts in early adulthood period and emerges under various conditions, the need for appreciation and the lack of empathy (Özel, 2012).

The narcissistic personality is a schizophrenic mood that lives in a state of concern, can not adapt to its surroundings, has only prejudice and withdrawal. The narcissist person lives passively and can not adapt to reality. Just like Sartre indicates, the only reality is hell. There is no place to escape, because there is nowhere to escape. It is also impossible to escape to its own self, because the narcissist's ability to govern himself is lost. Despite the fact that narcissist people are self-centered, they are abstracted up to they can not meet their own needs (Narr, 1980).

Naturally, we can confront the narcissistic personalities in political or academic leaders or famous artists. However, with careful observation, it turns out that the products of these people, who display a productive and creative image, are basically artificial, sloppy and lacking in depth (Evren, 1997, as cited in Timuroğlu \& İşcan, 2008).

The aim of this research is to determine the Narcissistic Personality Levels of university students connecting their successes and failures to internal causes. For this purpose, it is aimed to compare the narcissistic personality levels of the university students and especially the students of the Faculty of Education and the students of the Faculty of Sports Sciences in general by examining the differences of the narcissistic personality levels of the students in different parts of the universities according to sex, active sporting and age.

\section{Method}

In this study, in order to determine the narcissistic personality status of the students relational screening method was used in order to reach the findings about sex, age, active sporting, department, graduated high school, mother education level, father education level, mother profession and father occupation variables. According to Karasar (2000), screening models are research approaches that aim to describe either the past or present situation as it exists. It is tried to be defined as an event, an individual or an object, which is the subject matter of the research, as it is own conditions and as it is. In the context of this research, since it was tried to determine the narcissistic personality status of the students (aimed at presenting the present situation), this research is a descriptive research as well as an exploratory relational research since the relationship between variables and narcissistic personality is also examined (Creswell, 2005; Fraenkel \& Wallen, 2009)

\subsection{Working Group}

The research group of the study is composed of total of 364 university students studying Gazi University (n: 150), Hacettepe University (n: 114) and Ankara University (n: 100) Faculty of Sport Sciences and Faculty of Educationin the academic year 2017-2018. Table 1 gives the demographic information of university students.

\subsection{Data Collection Tool}

The narcissistic personality inventory used in the study was developed by Raskin and Hall (1988). The standardization of the Narcissistic Personality Inventory into the Turkish language was performed by Salim Atay (2009). With two different examples, internal reliability and structural validity of the scales were tested with the groups and Cronbach's Alpha value was found as 0.652 .

Factor analysis was applied to the validity of the inventory. As a result of exploratory factor analysis applied with the basic components method, 6 factors were found to be distributed according to the original structure of the questions. The rate of disclosure of the total variance of the factors is $60.8 \%$. For each question on the scale, 2 suggestions are presented and participants are asked to mark the suggestions that match them. In the Narcissistic Personality Scale;

- Authority sub-dimension;with 4 and 12. questions,

- Self-Efficacy sub-dimension; with 8, 13 and 15. questions,

- Superiority sub-dimension; with 1, 3 and 16.questions,

- Exhibitionism sub-dimension; with 2, 7 and 11. questions,

- Exploitation sub-dimestion; with 5,9 and 14. questions,

- Asserting a Right sub-dimension was measured with; 6 and 10. questions

\subsection{Analysis of Data}

In the analysis of the data collected by the researchers; frequency and percentage for the demographic characteristics of students; Descriptive statistics on narcissistic personality scores; Variance Analysis (one-way ANOVA, independent sample t-test) was used to compare mean scores in unrelated measures, and the Turkish test was used to determine which groups were significant differences. The Statistics Program (SPSS 23.0) was used in the analyzes. 


\section{Results}

In this section, findings related to the differences between the groups regarding the narcissistic personality scores of the students included in the sampling group were analyzed in terms of gender, age, active sporting, department, graduated high school, mother education level, father education level, mother profession and father occupation variables.

Table 1. Demographic information of students in Sports Sciences and Education Faculties

\begin{tabular}{|c|c|c|c|c|c|c|c|c|c|c|}
\hline \multirow[t]{2}{*}{ Faculty } & \multicolumn{2}{|l|}{ Gender } & \multicolumn{2}{|l|}{ Age } & \multicolumn{2}{|c|}{ Active Sporting } & \multicolumn{2}{|c|}{ Department } & \multicolumn{2}{|c|}{$\begin{array}{c}\text { Graduated High } \\
\text { School }\end{array}$} \\
\hline & $\mathrm{N}$ & $\%$ & $\mathrm{~N}$ & $\%$ & $\mathrm{~N}$ & $\%$ & $\mathrm{~N}$ & $\%$ & $\mathrm{~N}$ & $\%$ \\
\hline \multirow{4}{*}{$\begin{array}{l}\text { Sports Science } \\
\text { Faculty }\end{array}$} & $\begin{array}{l}\text { Female:55 } \\
\text { Male: } 129\end{array}$ & $\begin{array}{l}70.1 \\
29.9\end{array}$ & $\begin{array}{l}\text { 18-20: } 47 \\
\text { 21-23: } 90 \\
\text { 24-26: } 30 \\
\text { 27-30: } 11 \\
\text { 30-over: } 6\end{array}$ & $\begin{array}{l}25.5 \\
48.9 \\
16.3 \\
6 \\
3.3\end{array}$ & $\begin{array}{l}\text { Yes: } 118 \\
\text { No: } 66\end{array}$ & $\begin{array}{l}64.1 \\
35.9\end{array}$ & $\begin{array}{l}\text { Physical } \\
\text { education: } 65 \\
\text { Trainer: } 60 \\
\text { Administration: } 6 \\
\text { Recreation: } 53\end{array}$ & \begin{tabular}{l|}
35.3 \\
32.6 \\
3.3 \\
28.8
\end{tabular} & $\begin{array}{l}\text { Anatolian: } 83 \\
\text { Science: } 4 \\
\text { Vocational: } \\
34 \\
\text { Sport: } 8 \\
\text { Other: } 55\end{array}$ & $\begin{array}{l}45.1 \\
2.2 \\
18.5 \\
4.3 \\
29.9\end{array}$ \\
\hline & \multicolumn{2}{|c|}{ Mother's education } & \multicolumn{2}{|c|}{ Father's education } & \multicolumn{2}{|c|}{ Mother's occupation } & \multicolumn{2}{|c|}{ Father's occupation } & & \\
\hline & $\mathrm{N}$ & $\%$ & $\mathrm{~N}$ & $\%$ & $\mathrm{~N}$ & $\%$ & $\mathrm{~N}$ & $\%$ & & \\
\hline & $\begin{array}{l}\text { Primary school: } 72 \\
\text { Secondary school: } 46 \\
\text { High school: } 47 \\
\text { Undergraduate } \\
\text { Education: } 4 \\
\text { M.Sc.: } 15\end{array}$ & $\begin{array}{l}39.1 \\
25 \\
25.5 \\
2.2 \\
8.2\end{array}$ & $\begin{array}{l}\text { Primary school: } 49 \\
\text { Secondary school: } 25 \\
\text { High school: } 73 \\
\text { Undergraduate } \\
\text { Education: } 6 \\
\text { M.Sc.: } 31\end{array}$ & $\begin{array}{l}26.6 \\
13.6 \\
39.7 \\
3.3 \\
16.8\end{array}$ & $\begin{array}{l}\text { Officer: } 14 \\
\text { Worker: } 16 \\
\text { Craft: } 7 \\
\text { Retired: } 9 \\
\text { Not } \\
\text { working: } 114 \\
\text { Other: } 24 \\
\end{array}$ & $\begin{array}{l}7.6 \\
8.7 \\
3.8 \\
4.9 \\
62 \\
13\end{array}$ & $\begin{array}{l}\text { Officer: } 24 \\
\text { Worker: } 37 \\
\text { Craft: } 37 \\
\text { Retired: } 51 \\
\text { Not working: } 6 \\
\text { Other: } 29\end{array}$ & \begin{tabular}{l|}
13 \\
20.1 \\
20.1 \\
27.7 \\
3.3 \\
15.8
\end{tabular} & & \\
\hline \multirow{6}{*}{$\begin{array}{l}\text { Education } \\
\text { Faculty }\end{array}$} & \multicolumn{2}{|l|}{ Gender } & \multicolumn{2}{|l|}{ Age } & \multicolumn{2}{|c|}{ Active Sporting } & \multicolumn{2}{|c|}{ Department } & \multicolumn{2}{|c|}{$\begin{array}{c}\text { Graduated High } \\
\text { School }\end{array}$} \\
\hline & $\mathrm{N}$ & $\%$ & $\mathrm{~N}$ & $\%$ & $\mathrm{~N}$ & $\%$ & $\mathrm{~N}$ & $\%$ & $\mathrm{~N}$ & $\%$ \\
\hline & $\begin{array}{l}\text { Female: } 153 \\
\text { Male: } 27\end{array}$ & $\begin{array}{l}85 \\
15\end{array}$ & $\begin{array}{l}\text { 18-20: } 73 \\
\text { 21-23: } 102 \\
24-26: \quad 5\end{array}$ & $\begin{array}{l}40.6 \\
56.7 \\
2.8\end{array}$ & $\begin{array}{l}\text { Yes: } 50 \\
\text { No: } 130\end{array}$ & $\begin{array}{l}27.8 \\
72.2\end{array}$ & $\begin{array}{l}\text { Science: } 105 \\
\text { Maths: } 75\end{array}$ & $\begin{array}{l}58.3 \\
41.7\end{array}$ & $\begin{array}{l}\text { Anatolian: } 86 \\
\text { Science: } 7 \\
\text { Vocational: } 7 \\
\text { Other: } 80\end{array}$ & \begin{tabular}{l|}
47.8 \\
3.9 \\
3.9 \\
44.4 \\
\end{tabular} \\
\hline & \multicolumn{2}{|c|}{ Mother's education } & \multicolumn{2}{|c|}{ Father's education } & \multicolumn{2}{|c|}{ Mother's occupation } & \multicolumn{2}{|c|}{ Father's occupation } & & \\
\hline & $\mathrm{N}$ & $\%$ & $\mathrm{~N}$ & $\%$ & $\mathrm{~N}$ & $\%$ & $\mathrm{~N}$ & $\%$ & & \\
\hline & $\begin{array}{l}\text { Primary school: } 75 \\
\text { Secondary school: } 26 \\
\text { High School: } 60 \\
\text { Undergraduate } \\
\text { Education: } 12 \\
\text { M.Sc.:7 }\end{array}$ & $\begin{array}{l}41.7 \\
14.4 \\
33.3 \\
6.7 \\
3.9\end{array}$ & $\begin{array}{l}\text { Primary school: } 40 \\
\text { Secondary school: } 29 \\
\text { High School: } 39 \\
\text { Undergraduate } \\
\text { Education: } 30 \\
\text { M.Sc.: } 22 \\
\end{array}$ & $\begin{array}{l}22.2 \\
16.1 \\
32.8 \\
16.7 \\
12.2\end{array}$ & $\begin{array}{l}\text { Officer: } 18 \\
\text { Worker: } 13 \\
\text { Retired: } 7 \\
\text { Not } \\
\text { Working: } 124 \\
\text { Other: } 15 \\
\end{array}$ & \begin{tabular}{l|}
10 \\
7.2 \\
3.9 \\
70.6 \\
8.3
\end{tabular} & $\begin{array}{l}\text { Officer: } 47 \\
\text { Worker: } 37 \\
\text { Craft: } 21 \\
\text { Retired: } 46 \\
\text { Not Working: } 5 \\
\text { Other: } 24 \\
\end{array}$ & $\begin{array}{l}26.1 \\
20.6 \\
11.7 \\
25.6 \\
2.8 \\
13.3 \\
\end{array}$ & & \\
\hline
\end{tabular}

When Table 1 is examined; it can be seen that the Faculty of Sports Sciences has a total of 184, Faculty of Education has a total of 180 students. It is found to be $47(25.5 \%)$ student in the age range of $18-20$ years, $90(48.9 \%)$ in the age range $21-23,30(16.3 \%)$ in the age range of 24-26 years, $11(6 \%)$ in the age range of $27-30,118$ student $(64.1 \%)$ who are doing sports actively, 66 (35.9\%) students who are not doing sports actively; 65 (35.3\%) who study in physical education and sport teacher department, 60 (32.6\%) who study in the trainer department, $6(3.3 \%)$ who study in the management department, in the Faculty of Sports Sciences,

It is found to be $73(40.6 \%)$ students in the range of $18-20,101(56.1 \%)$ in the age range $21-23,30(6 \%)$ students, in the age range 24-26, 50\% (27.8)students who are doing sports actively, 130 (72.2\%) students who are not doing sports actively; 75 (41.7\%) who study in the science department, 105 (58.3\%) students, who study in the mathematics department in the Faculty of Education.

Table 2. Differences in narcissistic personality scores according to the age of the students who are educated in Sport Sciences and Education Faculties (One-Way ANOVA)

\begin{tabular}{|c|c|c|c|c|c|c|c|c|c|c|}
\hline Faculty & Sub-dimension & Age & $\mathbf{N}$ & $\bar{X}$ & $\begin{array}{l}\text { Source of } \\
\text { variance }\end{array}$ & $\begin{array}{l}\text { Sum of } \\
\text { squares }\end{array}$ & Ss & $\mathbf{F}$ & $\mathbf{p}$ & $\begin{array}{l}\text { The source of the } \\
\text { difference }\end{array}$ \\
\hline \multirow{6}{*}{ Sports Science } & \multirow{6}{*}{$\begin{array}{l}\text { Asserting a } \\
\text { right }\end{array}$} & $18-20$ & 47 & 3.36 & \multirow[t]{2}{*}{ Inter groups } & \multirow[t]{2}{*}{3.24} & \multirow[t]{2}{*}{4} & \multirow{6}{*}{2.41} & \multirow{6}{*}{$.05^{*}$} & \multirow{6}{*}{$\begin{array}{l}18-20 * \\
21-23\end{array}$} \\
\hline & & $21-23$ & 90 & 3.65 & & & & & & \\
\hline & & $24-26$ & 30 & 3.56 & \multirow[t]{3}{*}{ Intra groups } & \multirow{3}{*}{60.10} & \multirow{3}{*}{179} & & & \\
\hline & & $27-30$ & 11 & 3.45 & & & & & & \\
\hline & & 30-over & 6 & 3.83 & & & & & & \\
\hline & & Total & 184 & 3.56 & Total & 63.34 & 183 & & & \\
\hline \multirow{4}{*}{$\begin{array}{l}\text { Faculty of } \\
\text { Education }\end{array}$} & \multirow{4}{*}{ Exhibitionism } & $18-20$ & 73 & 3.91 & Inter groups & 1.66 & 2 & \multirow{4}{*}{3.14} & \multirow{4}{*}{$.04 *$} & \multirow{4}{*}{$\begin{array}{l}21-23 * \\
24-26\end{array}$} \\
\hline & & $21-23$ & 102 & 3.98 & & & & & & \\
\hline & & $24-26$ & 5 & 3.40 & Intra groups & 46.66 & 177 & & & \\
\hline & & Total & 180 & 3.94 & Total & 48.3 & 179 & & & \\
\hline
\end{tabular}

$p<.05^{*}$

When Table 2 was examined, a significant difference was found between the mean scores of the sub-dimension 
claiming according to the age variable of the students in the Faculty of Sports Sciences $[F(4,179)=2.41, p<.05]$. In the multiple comparison test results, a significant difference was found between the ages of 18-20 years and 21-23 years compared to the average scores of the subdimension claiming in the assessment of age of student $(\mathrm{p}<.05)$. The average score of the answers given to 18-20 age is 3.36, and the average score of answers given to 21-23 age is 3.65. There was no significant difference in other sub-dimensions according to age variable $(\mathrm{p}>.05)$.

A significant difference was found between the average scores of the exhibitionism sub-dimension $[F(2,177)=3.14, p$ $<.05]$ according to the age of the students studying at the Faculty of Education. In multiple comparison test results, in assessing the age of students, there is a significant difference between 21-23 years and 24-26 years according to the average scores of the exhibitionism sub-dimension ( $\mathrm{p}<.05$ ). The average score of answers given to 21-23 age is 3.98, and the average score of answers given to $24-26$ age is 3.40. There was no significant difference in other sub-dimensions compared to age variable ( $\mathrm{p}>.05)$.

Table 3. Differences in narcissistic personality scores according to the high school variable where they graduated, of the students studying in Sports Science and Education Faculties (One Way ANOVA)

\begin{tabular}{|c|c|c|c|c|c|c|c|c|c|c|}
\hline Faculty & Sub-dimension & $\begin{array}{l}\text { Graduate high } \\
\text { school }\end{array}$ & $\mathbf{N}$ & $\overline{\bar{X}}$ & $\begin{array}{ll}\begin{array}{l}\text { Source } \\
\text { variance }\end{array} & \text { of } \\
\end{array}$ & $\begin{array}{ll}\begin{array}{l}\text { Sum } \\
\text { squares }\end{array} & \text { of } \\
\end{array}$ & Ss & $\mathbf{F}$ & $\mathbf{p}$ & $\begin{array}{l}\text { The source of } \\
\text { the difference }\end{array}$ \\
\hline \multirow{10}{*}{$\begin{array}{l}\text { Faculty } \\
\text { Education }\end{array}$} & \multirow{5}{*}{ Superiority } & Anatolia & 86 & 3.64 & Inter groups & 9.73 & 3 & \multirow{5}{*}{3.57} & \multirow{5}{*}{$.01 *$} & \multirow{5}{*}{$\begin{array}{l}\text { Science* } \\
\text { Vocational }\end{array}$} \\
\hline & & Science & 7 & 4.57 & & & & & & \\
\hline & & Vocational & 7 & 3.28 & \multirow[t]{2}{*}{ Intra groups } & 159.65 & \multirow[t]{2}{*}{176} & & & \\
\hline & & Other & 80 & 3.94 & & & & & & \\
\hline & & Total & 180 & 3.79 & & 169.39 & 179 & & & \\
\hline & \multirow{5}{*}{ Asserting a right } & Anatolia & 86 & 3.62 & Inter groups & 4.93 & 3 & \multirow{5}{*}{3.82} & \multirow{5}{*}{$.01 *$} & \multirow{5}{*}{$\begin{array}{l}\text { Other* } \\
\text { Anatolia }\end{array}$} \\
\hline & & Science & 7 & 3.14 & & & & & & \\
\hline & & Vocational & 7 & 3.57 & \multirow[t]{3}{*}{ Intra groups } & 75.70 & \multirow[t]{2}{*}{176} & & & \\
\hline & & Other & 80 & 3.30 & & & & & & \\
\hline & & Total & 180 & 3.45 & & 80.64 & 179 & & & \\
\hline
\end{tabular}

$p<.05^{*}$

When Table 3 is examined, a significant difference was found between the average scores of the superiority subscale [F $(3,176)=3.57, \mathrm{p}<.05]$ according to the high school variables where they graduated, of the students studying in Education Faculty. In multiple comparison test results, a significant difference was found between Science High School and Vocational High School according to the average scores of the superiority sub-dimension assessment of high school situations where students graduated $(\mathrm{p}<.05$.) The average score for answers given for Science High School is 4.57, and the average score for answers given for Vocational High School is 3.28.

A significant difference was found between the mean scores of the claim subdimension $[\mathrm{F}(3,176)=3.82, \mathrm{p}<.05]$ according to the high school variables where students graduated, of the students studying at the Faculty of Education. In multiple comparison test results, a significant difference was found between other high schools and Anatolian High School compared to the average scores of the sub-dimension claiming the assessment of high school situations where students graduated. The average score for the answers given for the other high school is 3.30 and the average score for the answers given for the vocational high school is 3.62. There was no significant difference in the other sub-dimensions compared to the high school graduated ( $>$.05). In addition, among narcissistic personality scores of students who are studying at the Faculty of Sports Sciences, no significant difference was found for high school variable ( $p>.05$ ).

Table 4. Differences in narcissist personality scores according to the variables of mother education status of students in Sports Sciences and Education Faculties (One Way ANOVA)

\begin{tabular}{|c|c|c|c|c|c|c|c|c|c|c|}
\hline Faculty & $\begin{array}{l}\text { Sub-dimensio } \\
\text { n }\end{array}$ & Education status & $\mathbf{N}$ & $\overline{\boldsymbol{X}}$ & $\begin{array}{l}\text { Source of } \\
\text { variance }\end{array}$ & $\begin{array}{l}\text { Sum of } \\
\text { squares }\end{array}$ & Ss & $\mathbf{F}$ & $\mathbf{p}$ & $\begin{array}{l}\text { Source of the } \\
\text { difference }\end{array}$ \\
\hline \multirow{6}{*}{$\begin{array}{l}\text { Faculty of } \\
\text { Education }\end{array}$} & \multirow{6}{*}{ Superiority } & Primary School & 75 & 3.72 & \multirow{3}{*}{$\begin{array}{l}\text { Inter } \\
\text { Groups }\end{array}$} & \multirow{3}{*}{9.23} & \multirow{3}{*}{4} & \multirow{6}{*}{2.52} & \multirow{6}{*}{$\begin{array}{l}.43 \\
*\end{array}$} & \multirow{6}{*}{$\begin{array}{l}\text { Undergraduate * } \\
\text { High School }\end{array}$} \\
\hline & & Secondary School & 26 & 4.04 & & & & & & \\
\hline & & High School & 60 & 3.65 & & & & & & \\
\hline & & Undergraduate & 12 & 4.50 & \multirow{2}{*}{$\begin{array}{l}\text { Intra } \\
\text { Groups }\end{array}$} & \multirow[t]{2}{*}{160.16} & \multirow[t]{2}{*}{175} & & & \\
\hline & & MSc & 7 & 3.71 & & & & & & \\
\hline & & Total & 180 & 3.79 & Total & 169.39 & 179 & & & \\
\hline
\end{tabular}

\section{$p<.05^{*}$}

When Table 4 was examined, it was found that there was a significant difference between the mean scores of superiority subscale according to the variables of mother education level $[\mathrm{F}(4,175)=2.52, \mathrm{p}<.05]$ for the students who were student in Education Faculties. In the multiple comparison test results, there was a significant difference between the high school and undergraduate graduation according to the average scores of the superiority subscale in evaluating the mother education status of the students $(\mathrm{p}<.05)$. The average score of the answers given for high school is 3.65 and the average score of the answers given for the undergraduate is 4.50. In the other sub-dimensions, there was no significant difference compared to the mother education level variable ( $p>.05)$. In addition, there was no significant difference in the narcissistic personality scores of the students studying at Sports Sciences Faculty ( $p>.05)$. 
Table 5. Differences in narcissist personality scores according to the variables of father education level of students in Sport Sciences and Education Faculty (One Way ANOVA)

\begin{tabular}{|c|c|c|c|c|c|c|c|c|c|c|}
\hline Faculty & Sub-dimension & $\begin{array}{l}\text { Education } \\
\text { status }\end{array}$ & $\mathbf{N}$ & $\overline{\boldsymbol{X}}$ & $\begin{array}{ll}\begin{array}{l}\text { Source } \\
\text { variance }\end{array} & \text { of } \\
\end{array}$ & $\begin{array}{ll}\text { Sum } \\
\text { squares }\end{array}$ & Ss & $\mathbf{F}$ & $\mathbf{p}$ & $\begin{array}{l}\text { Source of the } \\
\text { difference }\end{array}$ \\
\hline \multirow{6}{*}{$\begin{array}{l}\text { Faculty } \\
\text { Education }\end{array}$} & \multirow{6}{*}{ Exhibitionism } & Primary school & 40 & 4.15 & \multirow[t]{3}{*}{ Inter Groups } & \multirow{3}{*}{3.08} & \multirow{3}{*}{4} & \multirow{6}{*}{2.98} & \multirow{6}{*}{$02 *$} & \multirow{6}{*}{$\begin{array}{l}\text { Primary school } * \\
\text { Secondary school } \\
\text { Primary school } * \\
\text { High school }\end{array}$} \\
\hline & & $\begin{array}{l}\text { Secondary } \\
\text { school }\end{array}$ & 29 & 3.76 & & & & & & \\
\hline & & High school & 59 & 3.86 & & & & & & \\
\hline & & Undergraduate & 30 & 3.97 & \multirow[t]{2}{*}{ Intra Groups } & \multirow[t]{2}{*}{45.24} & \multirow[t]{2}{*}{175} & & & \\
\hline & & M.Sc. & 22 & 3.95 & & & & & & \\
\hline & & Total & 180 & 3.94 & Total & 48.33 & 179 & & & \\
\hline
\end{tabular}

$p<.05^{*}$

When Table 5 was examined, it was found that there was a significant difference $[\mathrm{F}(4,175)=2.98, \mathrm{p}<.05]$ between the average points of exhibitionism sub-dimension according to the variables of father education level of the students in Education Faculties. In multiple comparison test results, there was a significant difference between primary school and secondary school and primary school and high school graduation according to the average scores of exhibitionism subdimension $(\mathrm{p}<.05)$. The average score for the answers given for primary school is 4.15 , the average score for answers given for secondary school is 3.76, and the average score for the answers given for high school is 3.86. There was no significant difference in other sub-dimensions according to father education level variable (p> .05). In addition, no statistically significant difference was found between the narcissistic personality scores for father education situation between among the narcissistic personality scores of the students who are studying at the Faculty of Sports Sciences

Table 6. Differences in narcissistic personality scores according to the father occupation variable of the students studying in Sports Sciences and Education Faculties (One Way ANOVA)

\begin{tabular}{|c|c|c|c|c|c|c|c|c|c|c|c|}
\hline Faculty & & Sub-dimension & Occupation & $\mathbf{N}$ & $\bar{X}$ & $\begin{array}{l}\text { Source } \\
\text { variance }\end{array}$ & $\begin{array}{ll}\begin{array}{l}\text { Sum } \\
\text { squares }\end{array} & \text { of } \\
\end{array}$ & Ss & $\mathbf{F}$ & $\mathbf{p}$ & $\begin{array}{l}\text { Source of the } \\
\text { difference }\end{array}$ \\
\hline \multirow{7}{*}{$\begin{array}{l}\text { Faculty } \\
\text { Education }\end{array}$} & \multirow{7}{*}{ of } & \multirow{7}{*}{ Self-efficacy } & Officer & 47 & 4.79 & \multirow[t]{3}{*}{ Inter Groups } & \multirow{3}{*}{12.19} & \multirow{3}{*}{5} & \multirow{7}{*}{3.51} & \multirow{7}{*}{$.00 *$} & \multirow{7}{*}{$\begin{array}{l}\text { Officer * } \\
\text { Retired }\end{array}$} \\
\hline & & & Worker & 37 & 5.27 & & & & & & \\
\hline & & & Craft & 21 & 4.95 & & & & & & \\
\hline & & & Retired & 46 & 5.43 & \multirow[t]{3}{*}{ Intra Groups } & \multirow{3}{*}{120.76} & \multirow{3}{*}{174} & & & \\
\hline & & & Not-working & 5 & 5.00 & & & & & & \\
\hline & & & Other & 24 & 5.33 & & & & & & \\
\hline & & & Total & 180 & 5.15 & Total & 132.95 & 179 & & & \\
\hline
\end{tabular}

$p<.05^{*}$

When Table 6 was examined, it was found that there was a significant difference $[F(5,174)=3.51, p<.05]$ between the average scores of self-efficacy subscale according to father occupation variable of the students studying at Faculty of Education. In the multiple comparison test results, there is a significant difference between civil servant and being retired status according to the average scores of self-efficacy subscale in the assessment of students' father professions $(p<.05)$. The average score of the responses to the officer is 4.79 , the average score of the responses to the retirement is 5.43. There was no significant difference in other sub-dimensions compared to father's occupation variable ( $>$.05). In addition, there was no significant difference for father profession variable among the narcissistic personality scores of the students studying at the Faculty of Sports Sciences ( $p>.05$ ).

There was no significant difference between the mean scores of the narcissist personality subscales compared to the variables of sex and active sport of students studying in Sports Sciences and Education Faculties as a result of t test analysis according to research findings ( $\mathrm{p}>.05)$.

In the one-way ANOVA results, there was no significant difference between the average scores of the narcissist personality subscales of the students studying Sports Sciences and Education Faculties compared to the department and mother's profession variables ( $p>.05)$. 
Table 7. Mean ( $\left.{ }^{-} \mathrm{X}\right)$ and standard deviation (ss) values of the narcissistic personality structure of students studying in Sport Sciences and Education Faculties.

\begin{tabular}{llccc}
\hline Department & Sub Dimension & $\mathbf{N}$ & $\overline{\boldsymbol{X}}$ & Ss \\
\hline & Authority & 184 & 2.74 & .60 \\
& Self-efficacy & 184 & 4.80 & .86 \\
& Superiority & 184 & 4.28 & 1.02 \\
Sports Science Faculty & Exhibitionism & 184 & 4.04 & .64 \\
& Exploitation & 184 & 4.70 & .80 \\
& Asserting a Right & 184 & 3.56 & .59 \\
& Total & 184 & 24.14 & 1.91 \\
& Authority & 180 & 2.67 & .58 \\
& Self-efficacy & 180 & 5.15 & .86 \\
& Superiority & 180 & 3.79 & .97 \\
Faculty of Education & Exhibitionism & 180 & 3.94 & .52 \\
& Exploitation & 180 & 4.64 & .67 \\
& Asserting a Right & 180 & 3.45 & .67 \\
& Total & 180 & 23.64 & 1.67 \\
\hline
\end{tabular}

When Table 7 is examined, it can be seen that the students who are studying at the Faculty of Sports Sciences have more authority, superiority, exhibitionism, exploitation and claiming behaviors than the students who are educated in the Faculty of Education; it is seen that the students who are studying at the Faculty of Education have more self-efficacy than the students who are studying at the Faculty of Sports Science.

\section{Discussion}

It has been examined whether there was a significant difference between the narcissistic personality scores of the students studying in Sports Science and Education Faculty compared to the gender, age, active sports making, high school, department, mother education level, father education level, mother profession and father occupation variables, in this study. As a result of the analyzes, it has been determined that there was a significant difference in age, graduation high school type, education level of mother, education level of father.

As a result of the analysis made to reveal the difference of narcissistic personality tendency of university students according to age variable, a significant difference was found between the mean scores of the sub-dimension claiming according to the age variable of the students studying in the Faculty of Sports Sciences. This means that students aged 21-23 are more likely to claim rights than students aged 18-20. As the age progresses, it seems that the students want to see more respect and deserve respect for their rights in parallel with the situation of becoming more educated, maturing and awareness. In addition, there was a significant difference between the average scores of the exhibitionism sub-dimension according to the age of the students studying at the Faculty of Education. That is, it was determined that 21-23-year-old students showed more exhibitionism behavior than 24-26-year-old students. This can be explained as the fact that students who have just started their education life or who are younger than their own age exhibit more word choice in crowded activities. Therefore, it can be said that as the age increases, students move away from the behavior of being the focus of interest. Çoban \& İrmiş (2018) found a significant difference between age and exploitation level. As the age passed by, it came to the conclusion that the level of exploitation fell. This result is in parallel with the research result. In their studies, Kocakula (2012), Koşan (2015) \& Özdemir (2017) found no significant difference between age variation and narcissist personality. These results do not coincide with the results of the study. In Tazegül ' $s$ work carried out in (2018a), narcissism scores of the sportsmen in the basketball branch are more than the sportsment in the footbal field. Tazegül, in its study in (2018b) found that steroid usage affects the level of narcissism of athletes. Tazegül \& Güven in their work carried out in 2017, determined narcissism scores of the athletes in the bodybuilding branch as 8,1429 . Tazegül \& Güven, in their work carried out in 2017 , found that narcissism scores of the student studying in the exercise and sports department were higher than narcissism scores of the student studying in the coaching and recreation department.

As a result of the analysis made in order to reveal the difference of the university student's narcissistic personality tendencies according to the variable of the high school type that students are graduated, a significant difference was found between the average scores of the superiority subscale of the students studying at the Faculty of Education compared to the high school variable that they are graduated. In other words, it was determined that the students who graduated from the Science High School showed more superior behavior than those who graduated from Vocational High School. It is understood that students who graduated from Science High School see themselves as more special, extraordinary, and great. Therefore, these students may think that they are better educated in high school than others. In addition, a significant difference was found between the mean scores of the claim sub-dimension asserting a right by the students studying at the Faculty of Education according to the high school variable that students graduated. In other words, it has been found that students who graduated from Vocational School have asserted more rights than students 
who graduated from other high schools. This can be expressed as the fact that graduates of the Vocational School can defend their rights more and wish to see the respect they deserve compared to others. In the study with managers conducted by Çoban \& İrmiş (2018), it has been suggested that managers who are educated at associate degree level are more exhibitors than managers who are educated at undergraduate and graduate level in relation to educational status and exhibitionism. They pointed out that it is not surprising that managers of associate degree graduates tend to show themselves more in terms of education level. In this regard, behaviours of the students who graduated from Science High School considering themselves as special, extraordinary, and behavihours of the students of the Vocational High School graduates defending their rights and being respected have shown parallelism.

As a result of analyzing the difference of the narcissistic personality tendencies of the university students according to the educational level of the mother, a significant difference was found between the average scores of the superiority subscale according to the education level of the students in the Education Faculties. In other words, students whose mothers graduated with a bachelor's degree show higher superiority than those with high school graduates. Students with a mothers' education as undergraduate status see themselves as better, more specific and more unusual. In this regard, it can be said that more educated mothers are more supportive of their children and show more interest in.

As a result of the analysis made to reveal the difference of the narcissistic personality tendencies of the university students compared to the father education state variable, a significant difference was found between the average scores of the exhibitionism sub-dimension compared to students' father education status studying at the Faculty of Education. That is, the students, whose fathers were graduated from high school show more exhibitism behovior than those whose fathers were graduated from primary school, whereas those with primary school graduation show more exhibitism behovior than those with secondary school graduation. This indicates that the students whose the father's education status is high school and primary school are more likely to make exhibitions of show and to be center of interest in a crowd compared to others. This result may have revealed randomly.

As a result of the analysis made to reveal the difference of the narcissistic personality tendencies of the university students compared to the father occupation variable, a significant difference was found between the average scores of self-efficacy subscale compared to father's occupation variable of the students studying at the Faculty of Education. Therefore, retired fathers show more competence than civil servants. This case shows that students, whose fathers' occupation are retired, are more confident, more attentive, know what they are doing, believe that they will be successful and important people, and find themselves adequate. It can be said that the students have gained more confidence in the fact that they have completed their working life and achieved certain economic security

There was no significant difference between the scores of the narcissist personality subscales according to the gender variable of the students who were educated in Sports Sciences and Education Faculties. In some studies, it was found that the difference between genders was not statistically significant. (Cihangiroğlu, Teke, Uzuntarla \& Uğrak, 2015; Kocakula, 2012; Koşan, 2015; Orhan 2014). These findings overlap with the results of the research. Aslan, Mert \& Yildiz (2014) found that narcissistic personality significantly differentiated by gender and that men were more narcissistic than women. Tschanz et al. (1998) and Tammy et al (2007) found that men are more narcissistic than women. These results are inconsistent with the results of the research. These results are inconsistent with the results of the research.

There was no significant difference between the mean scores of the narcissist personality subscales of the students studying in Sports Sciences and Education Faculties compared to those making active sports variable. Elman et al. (2003) determined the level of narcissism of footballers to be as 19.4, the level of narcissism of sportsmen in basketball and rugby branches to be as 17.8, and the narcissism levels of non-athletic individuals to be as 15.2. These results are not parallel to the research results. Sohrabi and colleagues (2011) compared the levels of narcissism of athletes in the multiple-contact sport (boxing and karate) and the non-contact (swimming, gymnastics) sports branch and found a statistically significant difference.

There was no significant difference between the mean scores of the narcissist personality subscales of students studying in Sports Sciences and Education Faculties compared to department and maternal occupational variables.

It seems that the authority, superiority, exhibitionism, exploitation and claiming behaviours of students studying in the School of Sports Sciences are greater than the students studying in the Faculty of Education that the self-efficacy behaviors of the students studying at the Faculty of Education are greater compared to the students studying at the Faculty of Sports Sciences. This case can be explained in such a way that the students studying in the Faculty of Sports Scienses are more likely to establish authority over others, to believe that they are better than others, to be special and extraordinary, to be a center of interest, to make shows, to manipulate people, to convince people what they say, to wish to see the respect they deserve, and to show expectation from people more. It can be interpreted that the students who are educated in the Faculty of Education exhibit more confident behaviors, believe that they will be successful and 
important people, and show more self-sufficient behaviors. In this context, it can be said that the students of Faculty of Sports Sciences are more prone to narcissistic personality behaviors. The main reason why the sportsman are more narcissists than the non-sportsman are thought to be the athletes have aesthetic and beautiful physics (Tazegül, 2013).

\section{Recommendations and Conclusion}

Narcissistic personality behavior is one of the serious problems that prevent students from showing their actual performance in universities. It is important to take the necessary steps to improve negative attitudes, unless university students' narcissistic personality trends do not reach exaggerated, diseased and harmful dimensions, before starting the professional life. At this point, interventions can be made to change students' unrealistic thoughts in psychological counseling services offered at universities. Furthermore, supportive practices for encouraging behavior such as self-esteem-self-confidence, listening, giving importance to others, showing love-respect to others, empathyin guidance services, in school curricula, in extracurricular will contribute to the resolution of the narcissist personality problem. In addition, qualitative research can be done to reveal the causes of narcissistic personality behavior of university students. In addition, to eliminate the lack of literature on narcissism, researchers are suggested to work in sociological areas. The reasons of having more narcissistic personality behaviors in the students of the Faculty of Sports Sciences can be investigated.

\section{References}

Aslan, M., Mert, H. Ş., \& Yıldı, M. (2014). An examination of the relationship between narcissistic personality and forgiveness. 2nd International Congress of Social Sciences from China to the Adriatic, verbal notification, 147-153.

Atay, S. (2009). Standardization of Narcissistic Personality Inventory to Turkish, Journal of Gazi University Faculty of Economics and Administrative Sciences, 11(1), 181-196.

Cihangiroğlu, N., Teke, Y., Uzuntarla, A., \& Uğrak, U. (2015). Analysis of the relationship between narcissistic personality trends and organizational commitment, Journal of Management and Economics Research, 13(1), 1-18. https://doi.org/10.11611/JMER400

Çoban, H., \& İrmiş, A. (2018). A research on narcissism in managers, International Management Economics and Business Review, 14(1), 123-145.

Cresswell, J. W. (2005). Educational research: Planning, conducting, and evaluating quantitative and qualitative research (2nd Ed.). N. J.: Pearson.

Elman, F. W., \& Mckelvie, J. S. (2003). Narcissism in Football Players: Stereotype or Reality., Athletich insightthe online journal of sport psychology, 5(1), 38-46.

Fraenkel, J. R., \& Wallen, N. E. (2009). How to design and evaluate research in education (7th Ed.). PA: McGraw-Hill.

Karaaziz, M. \& Atak, İ. (2013). A review on research on narcissism and narcissism. Object, 1(2), 44-59.

Karasar, N. (2000). Scientific Research Methods. Ankara: Nobel Publication.

Kocakula, Ö. (2012). Impact of decision-making processes on narcissistic and obsessive compulsive personality disorders, Master's thesis, Adnan Menderes University, Aydın.

Kohut, H. (1971). The analysis of the self. New York: International University Press

Kohut, H. (1977). Restoration of the self. New York: International University Press.

Koşan, Y. (2015). Examination of the relationship of the university student's facebook usage with narcissism and aggression levels. Master's thesis, Yüzüncü Yıl University, Van.

Narr, W. D. (1980). The selling of narcism, Dialectical Antropology (pp. 63-73).

Orhan, G. (2014). Narcissism etiology and its relation with religioisity. Published master's thesis, Erciyes University, Kayseri.

Özakkaş, T. (2006). Narcissistic and borderline personality disorders. Istanbul: Litera Publishing.

Özdemir, H. E. (2017). The relationship between attachment styles and narcissism in a group of university students: mediating role of rejection sensitivity. Master's Thesis, Işı University, Istanbul.

Özel, İ. (2012). Narcissism in religionists. International Social Research Journal, 7(32), 310-327.

Özsaydın, S. (1984). Psychiatry. Virtual Printing, 7, İstanbul.

Raskin, R., \& Hall, T. (1988). A Principal-Component Analysis of the Narcissistic Personality Inventory and Further Evidence of its Construct Validity, Journal of Personality and Social Psychology Bulletin, 27, 151-161. 
https://doi.org/10.1037/0022-3514.54.5.890

Rozenblatt, S. (2002). In defence of self: the relationship of self- esteem and narcissim to aggressive behavior long island university, psychology. Published Doctoral Dissertation, USA.

Sohrabi, F., Atashak, S., \& Aliloo, M. M. (2011). Psychological Profile of Athletes in Contact and Non-Contact Sports, Middle-East Journal of Scientific Research, 9(5), 638-644.

Tammy, B. D., Thompson, A., Barry, T. C., Lochman, E. J., Adler, K., \& Hill, K. (2007). The Importance of Narcissism in Predicting Proactive and Reactive Aggression in Moderately to Highly Aggressive Children, Aggressive Behavior., 33, 185-197. https://doi.org/10.1002/ab.20198

Tazegül, Ü. (2013). Examination of the relationship between motivational orientations and narcissism levels of boxers, The Journal of Academic Social Science Studies, 6(5), 679-691.

Tazegül, Ü. (2018). Sport, Narcissism and Body Sense. Detay Publication, Ankara.

Tazegül, Ü. (2018a). Determination of Relationship between Basketball and Soccer's Narcissism Levels and Body Perceptions, Journal of Social and Humanities Sciences Research (JSHSR), 5(17), 212-221.

Tazegül, Ü. (2018b) Comparison of the Narcissism Level of the Bodybuilders before and after the Application of Anabolic Steroid Cure, Universal Journal of Educational Research, 6(6), 1149-1152.

Tazegül, Ü., \& Güven, Ö. (2017). An Investigation of the Relationship Between the Levels of Narcissism and Body Perception of Male Athletes in the Bodybuilding Branch. Journal of Social And Humanities Sciences Research (JSHSR), 4(13), 1505-1510. https://doi.org/10.26450/jshsr.227

Tazegül, Ü., \& Özdemir, A. (2018). Comparison of the Narcissism Levels of the Students in the School of Physical Education and Sports of İstanbul Gelişim University, 6th International Conference on Science, Culture, and Sport, 25-27, April.

Timuroğlu, K., \& İșcan, F. (2008). Narcissism and job satisfaction in the workplace, Journal of Economics and Administrative Sciences, 22(2), 239-264.

Tschanz, T. B., Morf, C. C., \& Turner, W. C. (1998). Gender differences in the structure of narcissism: A multi-sample analyses of the narcissistic personality inventory. Sex Roles, 38, 863-870. https://doi.org/10.1023/A:1018833400411

Turkish Language Association (2018). Great Turkish Dictionary. www.tdk.gov.tr.

\section{Copyrights}

Copyright for this article is retained by the author(s), with first publication rights granted to the journal.

This is an open-access article distributed under the terms and conditions of the Creative Commons Attribution license which permits unrestricted use, distribution, and reproduction in any medium, provided the original work is properly cited. 